\title{
Development of gonadotrophin-binding sites in the immature rat ovary
}

\author{
J. J. Peluso, R. W. Steger and E. S. E. Hafez \\ Reproductive Physiology Laboratories, C. S. Mott Center for Human Growth and Development, \\ Wayne State University School of Medicine, Detroit, Michigan 48201, U.S.A.
}

\begin{abstract}
Summary. There was a temporal relationship between ovarian development and the sites to which ${ }^{125}$ I-labelled gonadotrophins became bound. Labelled human LH and FSH bound uniformly to 5- and 15-day-old ovaries. At 21 days, heavy FSH and light LH binding was observed over the granulosa cells of some antral follicles. LH binding to the granulosa cells increased at Day 33 and again at Day 38. Quantitative determination by $\gamma$-ray spectrophotometry of binding to ovarian sections showed that LH binding gradually increased with advancing age, but FSH binding remained relatively constant between Days 5 and 33 with a significant increase between Days 33 and 38.
\end{abstract}

\section{Introduction}

Three phases of development of the rat ovary can be distinguished by the response to gonadotrophins (Rennels, 1951). Ovaries of infantile rats (0-6 days of age) fail to respond to PMSG while ovaries of young rats (7-15 days of age) become heavier and synthesize steroids when exposed to PMSG. The increase in ovarian weight is due to an increase of interstitial tissue and not to follicular growth. Before puberty ( 16 days of age to the first ovulation) PMSG injections cause an increase in follicular growth, oestrogen synthesis (Rennels, 1951) and ovulation (Hillensjo, Barnea, Nilsson, Herlitz \& Ahrén, 1974). Ovulation is not induced in 35 -day-old rats treated with 15 i.u. HCG, although large follicles are present (Meijs-Roelofs, Uilenbroek, Osman \& Welschen, 1974). Presl, Pospíšil, Figarová \& Wagner (1972) showed that ${ }^{125}$ I-labelled HCG bound to thecal and interstitial cells of 8-9-day-old rat ovaries but that little binding occurred to the granulosa cells, even of 30-day-old rats. The present experiment was therefore designed (a) to determine the amount of ${ }^{125}$ I-labelled gonadotrophins which will bind to rat ovaries of different ages; and (b) to identify the ovarian structures to which these gonadotrophins bind.

\section{Materials and Methods}

Four litters of Wistar rats born in our colony were housed in controlled environmental conditions $\left(24^{\circ} \mathrm{C}, 45 \%\right.$ humidity and $14 \mathrm{hr}$ light $\left./ 24 \mathrm{hr}\right)$. Each litter was reduced to 8 young at 5 days, and weaned at 22 days of age. Under these conditions, vaginal opening occurs on Day 42 in this colony. Groups of 5 rats were killed at 5,15,21,33 and 38 days of age. The ovaries were placed in an embedding medium, OCT compound (Ames Co., Elkhart, Indiana), frozen in a solid $\mathrm{CO}_{2}$-ethanol bath and stored at $-20^{\circ} \mathrm{C}$.

Hormone preparations. Purified human FSH and LH (Calbiochem, La Jolla, California) were used; the LH had a biological potency of $2000 \mathrm{i} . u$. $/ \mathrm{mg}$, as judged by the ovarian ascorbic acid depletion bioassay, and an FSH activity of $4 \mathrm{i} . \mathrm{u} . / \mathrm{mg}$ in the HCG augmentation bioassay. The ${ }^{125}$ I-labelled LH did not bind to an FSH antiserum which was pre-absorbed with human LH. The human FSH pi ?paration had a biological potency of $3500 \mathrm{i} . \mathrm{u} . / \mathrm{mg}$ when tested in the HCG-augmentation bioassay. The LH contamination was $5 \%$ when tested in the OAAD bioassay and against a pre-absorbed LH antiserum. 
The gonadotrophins were iodinated with ${ }^{125}$ I by the chloramine-T method (Greenwood, Hunter \& Glover, 1963). After iodination, the reaction mixture was passed through a Biogel P-60 column (Bio-Rad, Richmond, California) to separate the ${ }^{125} \mathrm{I}$-labelled gonadotrophin from the free ${ }^{125} \mathrm{I}$. The specific activity was approximately $26 \mu \mathrm{Ci}$ and $50 \mu \mathrm{Ci} / \mu \mathrm{g}$ protein for $\mathrm{LH}$ and $\mathrm{FSH}$, respectively.

Ovine LH (NIH-LH-S17) and FSH (NIH-FSH-S19) were used to compete against the ${ }^{125}$ Ilabelled gonadotrophins in control studies.

Binding of ${ }^{125}$ I-labelled gonadotrophins. Frozen sections were cut at $10 \mu \mathrm{m}$ on a cryostat and placed on glass slides for autoradiography and histology or on coverslips for measurement of binding and estimation of protein. The slides and coverslips were placed in a moist chamber and stored at $4^{\circ} \mathrm{C}$. Sections for histology were fixed in $70 \%$ ethanol and stained with haematoxylin and eosin.

To identify the cellular binding sites, sections were incubated for $1 \mathrm{hr}$ at $37^{\circ} \mathrm{C}$ with ${ }^{125}$ I-labelled LH $\left(4.8 \times 10^{4} \mathrm{ct} / \mathrm{min} / 25 \mu \mathrm{l}\right)$ or ${ }^{125} \mathrm{I}$-labelled FSH $\left(6.7 \times 10^{4} \mathrm{ct} / \mathrm{min} / 25 \mu \mathrm{l}\right)$. After incubation the sections were washed for $10 \mathrm{~min}$ in cold phosphate-buffered saline $(\mathrm{pH} \mathrm{7.6)}$, rinsed in distilled water for $5 \mathrm{~min}$ and air dried. The sections were then dipped in NTB-3 nuclear track emulsion, exposed for 10-15 days at $4^{\circ} \mathrm{C}$ and developed (Midgley, 1972). Sections on coverslips were encircled with a wax ring and incubated for $1 \mathrm{hr}$ at $37^{\circ} \mathrm{C}$ with either ${ }^{125} \mathrm{I}$-labelled $\mathrm{LH}\left(1.6 \times 10^{4} \mathrm{ct} / \mathrm{min} / 25 \mu \mathrm{l}\right)$ or ${ }^{125} \mathrm{I}$ labelled FSH $\left(1.7 \times 10^{4} \mathrm{ct} / \mathrm{min} / 25 \mu \mathrm{l}\right)$. The sections were then washed, air dried and counted in a gamma counter for $5 \mathrm{~min}$. Coverslips without sections were also incubated with the same amounts of labelled hormones to estimate background and non-specific binding (Midgley, 1972). Binding was expressed as the number of counts above background/ $\mu$ g protein. The amount of protein was determined in alternate $10 \mu \mathrm{m}$ sections using a modified Lowry procedure (Lowry, Rosebrough, Farr \& Randall, 1951).

The ovaries were sectioned over a 5-day period with one ovary from each age group being sectioned on the same day. Statistical comparisons were made by an analysis of variance.

\section{Results}

Preliminary autoradiographic studies showed that a dose of LH or FSH of 4-5 $\times 10^{5} \mathrm{ct} / \mathrm{min} / 25 \mu \mathrm{l}$ was required to visualize specific binding sites within the ovary. However, a lower dose $\left(1.6-1.7 \times 10^{4}\right.$ $\mathrm{ct} / \mathrm{min} / 25 \mu \mathrm{l}$ ) gave a better quantitative estimate of gonadotrophin binding. The $10 \mu \mathrm{m}$ ovarian sections contained an average of $11.1 \mu \mathrm{g}$ protein (range $8 \cdot 8-14 \cdot 7 \mu \mathrm{g} / \mathrm{section}$ ) and bound $2-3 \%$ of the total ${ }^{125}$ I-labelled gonadotrophin added. When $0.5 \mathrm{mg}{ }^{125} \mathrm{I}$-labelled LH or FSH was incubated with $0.6 \mathrm{mg}$ ovine LH or FSH, respectively, the amount of binding was reduced by approximately $50 \%$.

Table 1. Developmental changes in mean \pm S.E.M. ovarian gonadotrophin binding (ct/min/ $/ \mu \mathrm{g}$ protein above background) and uterine weight $(\mathrm{mg})$ of rats (5/group)

\begin{tabular}{lccccc}
\hline & \multicolumn{5}{c}{ Age (days) } \\
\cline { 2 - 6 } & 5 & 15 & 21 & 33 & 38 \\
\hline LH binding & $22 \pm 14$ & $39 \pm 15$ & $45 \pm 23$ & $23 \pm 4$ & $78 \pm 18$ \\
FSH binding & $20 \pm 12$ & $18 \pm 10$ & $31 \pm 7$ & $44 \pm 5$ & $102 \pm 10$ \\
Uterine weight & $9 \cdot 5 \pm 0 \cdot 42$ & $26 \cdot 6 \pm 0 \cdot 76$ & $46 \cdot 0 \pm 3 \cdot 1$ & $108 \pm 13 \cdot 3$ & $91 \cdot 0 \pm 3 \cdot 7$ \\
\hline
\end{tabular}

Both gonadotrophins were bound in 5-day-old rats (Table 1). Although the amount of binding of ${ }^{125}$ I-labelled LH gradually increased from Days 5 to 38, the differences between ages were not statistically significant with one exception. Because of a slight decline in LH binding at Day 33, the amount of ${ }^{125}$ I-labelled LH binding was significantly greater $(P<0.05)$ on Day 38 than Day 33. Binding of ${ }^{125}$ I-labelled FSH was also greater $(P<0.05)$ on Day 38 than on any other day.

The ovaries contained many preantral follicles at 5 days of age and antral follicles at Day 15 . At Days 5 and 15 both ${ }^{125}$ I-labelled gonadotrophins bound uniformly to all ovarian structures (Pl. 1, Figs 1 and 2), but no binding occurred over the antrum of follicles. 
PLATE 1.
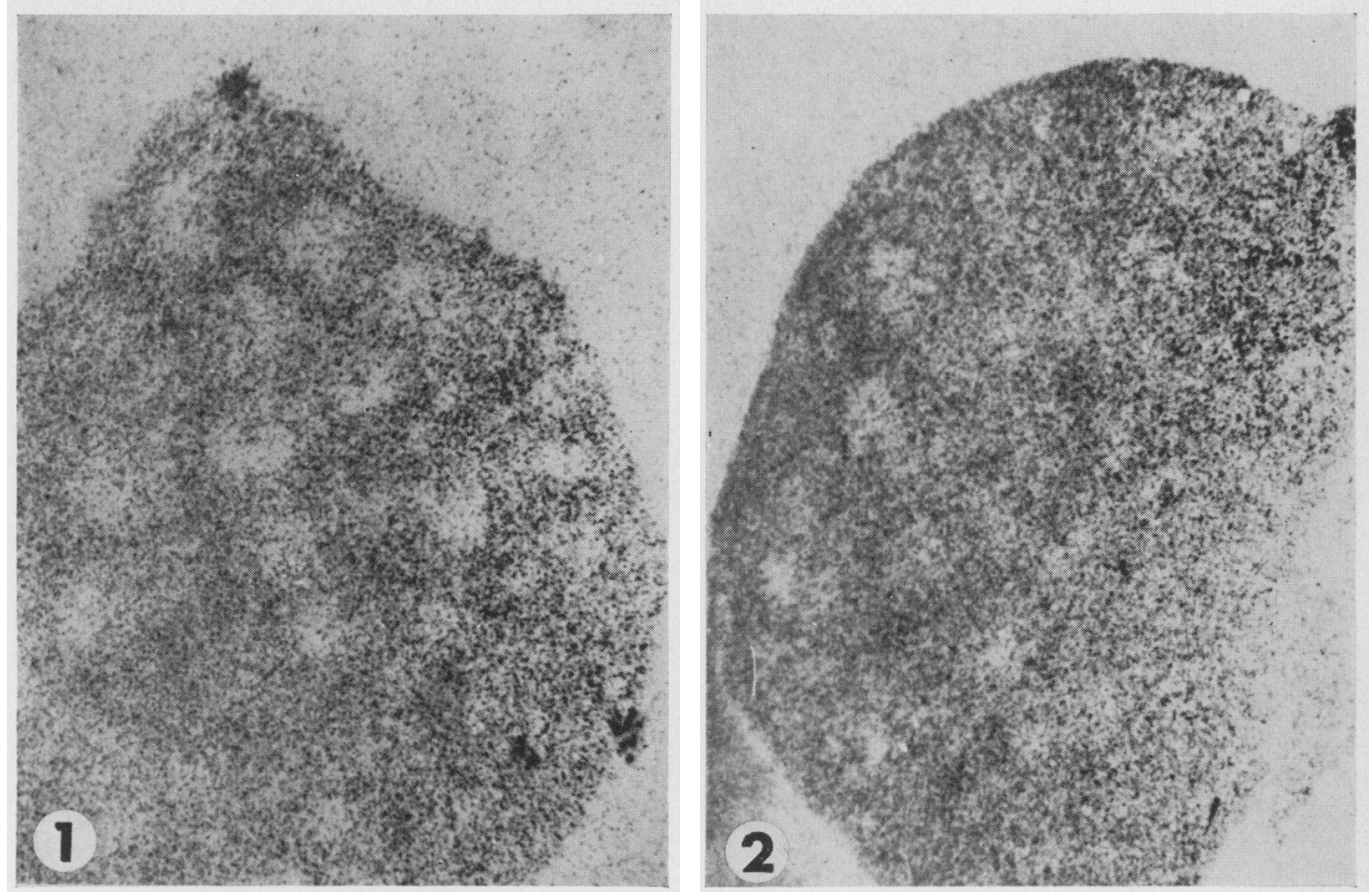

Figs 1 and 2. Autoradiographs of a 15-day-old rat ovary showing uniform binding of ${ }^{125}$ I-labelled human FSH (Fig. 1) and ${ }^{125} \mathrm{I}$-labelled human LH (Fig. 2) except over the antra of the follicles. $\times 260$.
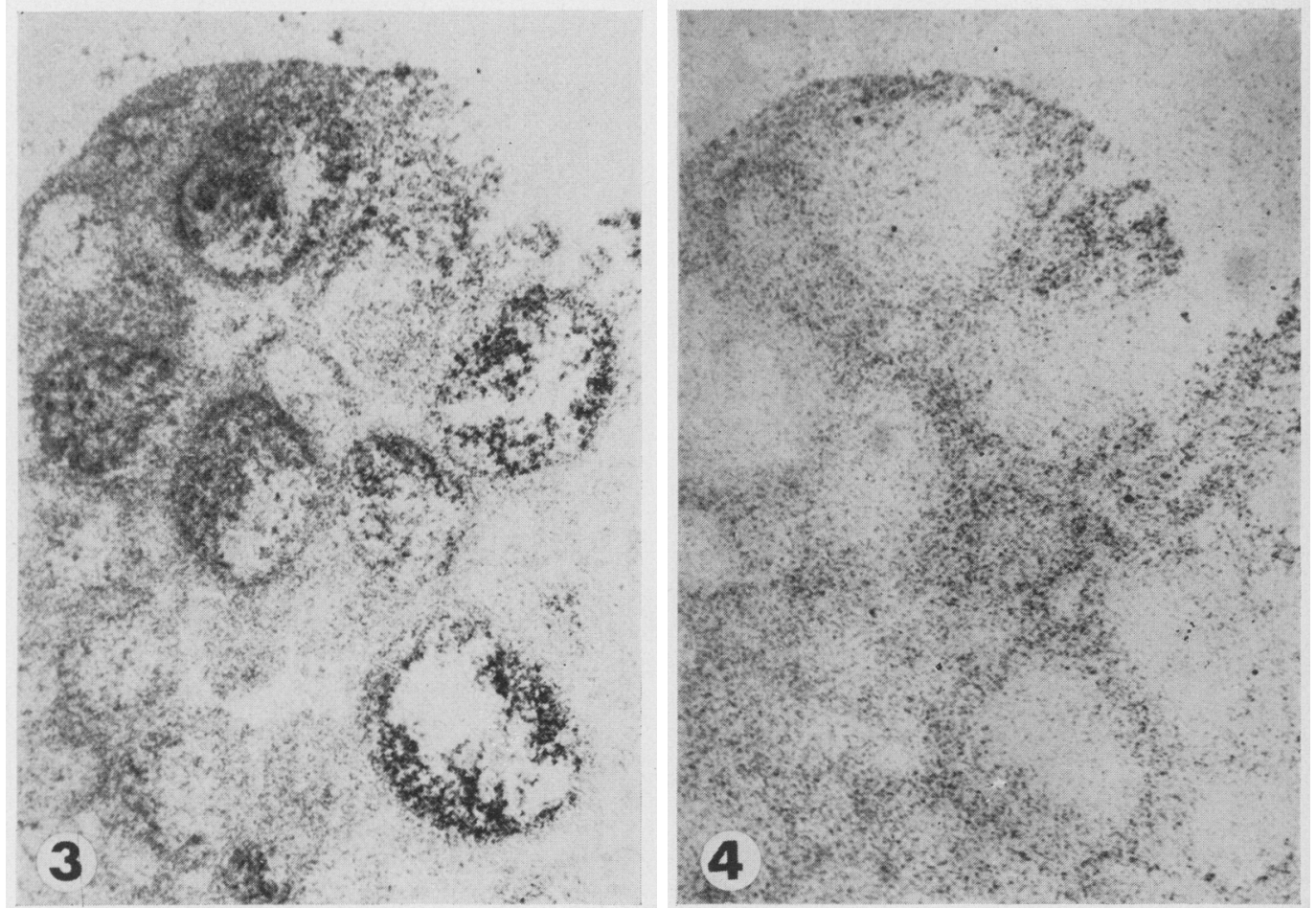

Figs 3 and 4. Adjacent sections taken from an ovary of a 21 -day-old rat. Note the heavy label of ${ }^{125}$ I-labelled FSH over the granulosa cells of some antral follicles (Fig. 3) and the light binding of ${ }^{125}$ l-labelled LH over the interstitial and thecal cells (Fig. 4). $\times 125$. 
PLATE 2

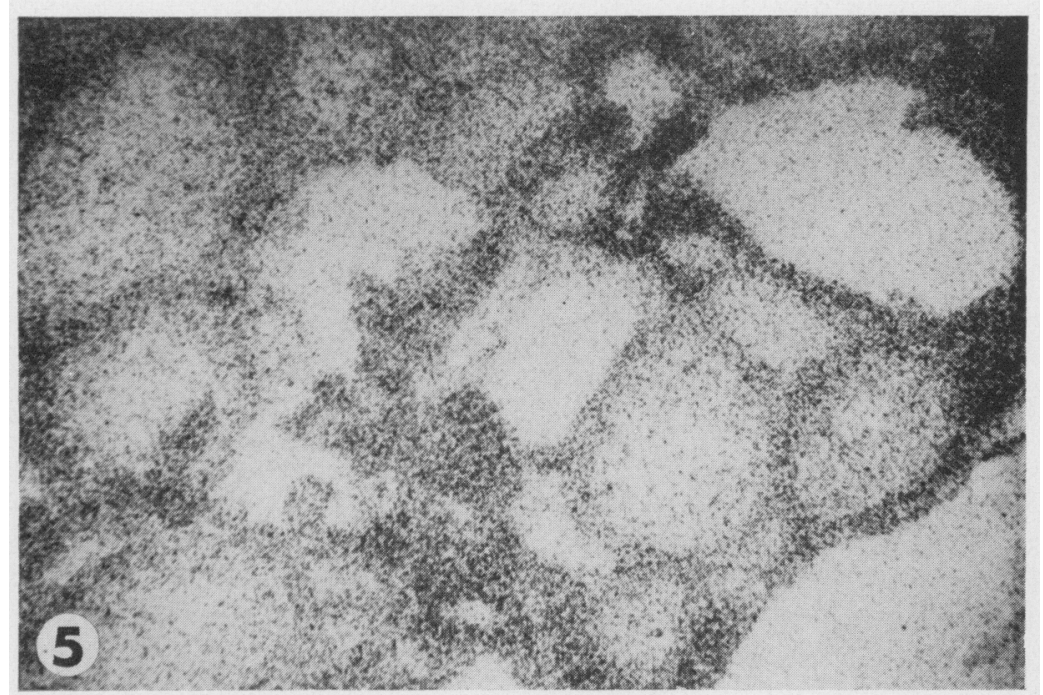

Fig. 5. Autoradiograph of a 33 -day-old rat ovary showing the binding of ${ }^{125}$ [-labelled LH to the interstitial, thecal and granulosa cells. $\times 150$.

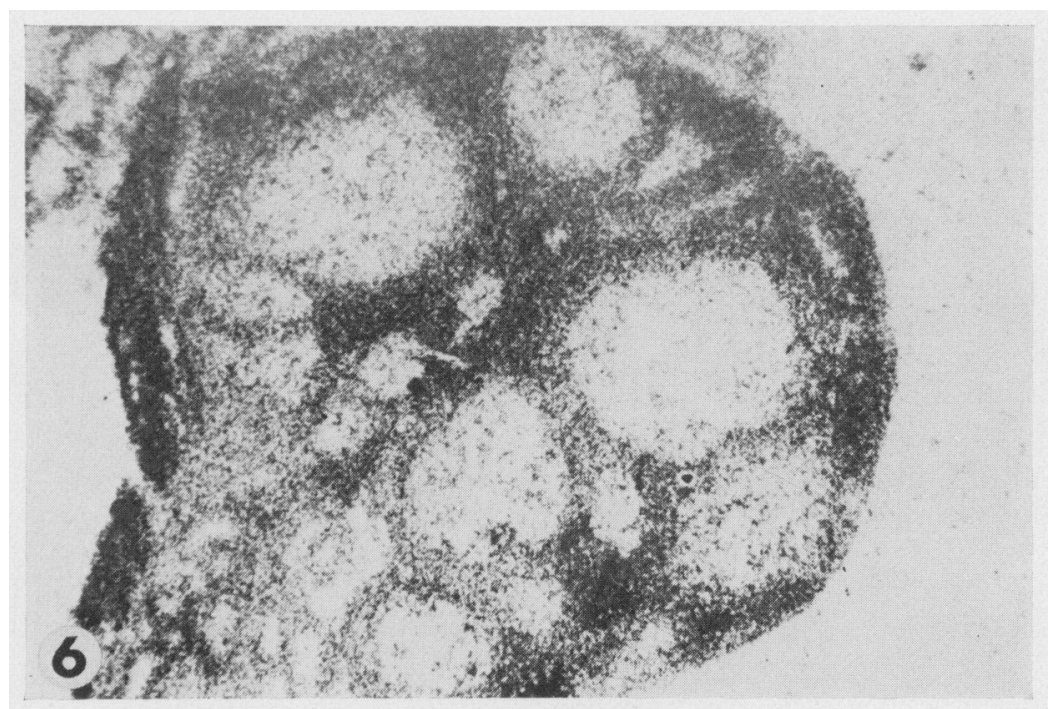

Fig. 6. An autoradiograph of a 38-day-old rat ovary showing the increased binding of ${ }^{125}$ I-labelled LH to all ovarian cell types. $\times 150$. 
Changes in the cellular binding sites were observed at Day 21 . The ovaries contained many medium-sized follicles (approximately $250 \mu \mathrm{m}$ in diameter). The granulosa cells of many of these follicles showed intense binding with ${ }^{125}$ I-labelled FSH (Pl. 1, Fig. 3); binding of ${ }^{125} \mathrm{I}$-labelled LH was observed mainly over the interstitial and thecal cells and very slightly over the granulosa cells (P1. 1, Fig. 4). At Day 33, more labelled LH became bound to the thecal and granulosa cells (P1. 2, Fig. 5). A further increase in binding of ${ }^{125}$ I-labelled LH was observed over the thecal and granulosa cells at Day 38 (P1. 2, Fig. 6).

The developmental changes in ovarian binding of ${ }^{125}$ I-labelled gonadotrophins were associated with a gradual increase in uterine weight (Table 1).

\section{Discussion}

The present data indicate that LH and FSH can bind to the ovaries of 5- and 15-day-old rats. By Day 15 interstitial and thecal cells have developed (Dawson \& McCabe, 1951) and it is to these tissues that the gonadotrophins bind. Although gonadotrophins were not thought to regulate ovarian function at this early age (Hertz, 1963), antiserum to either LH or FSH, given daily from Days 5 to 15, interferes with the development of interstitial tissue (Schwartz, Anderson, Nequin \& Ely, 1974). Since serum FSH and LH are both elevated during this period (Meijs-Roelofs et al., 1974), these gonadotrophins could play a role in the development of the interstitial cells and the initiation of follicular development.

By Day 21, the granulosa cells of some antral follicles bind ${ }^{125}$ I-labelled FSH. Oestrogen pretreatment increases the amount of $\left[{ }^{3} \mathrm{H}\right] \mathrm{FSH}$ taken up by the ovary (Goldenberg, Vaitukaitis \& Ross, 1972). The ovary of a 14-day-old rat not only contains but also releases considerable amounts of oestrogen (Cierciorowska \& Russfield, 1968). The oestrogen, which is synthesized and secreted by Day 15 of age, as indicated by the increase in uterine weight, could induce the formation of FSH receptors within the granulosa cells of medium-sized antral follicles. Since FSH could increase oestrogen synthesis, which in turn increases $\left[{ }^{3} \mathrm{H}\right.$ ]thymidine incorporation and cell division within the granulosa cells (Goldenberg et al., 1972; Reiter, Goldenberg, Vaitukaitis \& Ross, 1972), FSH binding could thus initiate a sequence of events leading to growth. The granulosa cells of only a few follicles were found to bind the ${ }^{125}$ I-labilled FSH. Many of the follicles that did not bind FSH by Day 21 were small and may not have developed FSH-binding sites. It is also possible that some of these follicles were atretic, since atretic follicles lack receptors for LH, FSH (J. J. Peluso, unpublished) and oestrogen (Richards, 1975).

The ability of the granulosa cells to bind ${ }^{125}$ I-labelled LH was apparent only by Day 33 . With advancing age, follicular size and $\mathrm{LH}$ binding increased. A similar relationship between follicular size and LH receptors was observed in the pig (Channing \& Kammerman, 1973). Since treatment with FSH induces the formation of LH receptors in the granulosa cells (Zeleznik, Midgley \& Reichert, 1974), the binding of FSH could enhance follicular development and induce LH receptors within these cells. Once a sufficient number of LH receptors have been induced, then the follicles should be able to ovulate and luteinize in response to a gonadotrophin surge.

\section{References}

Channing, C.P. \& Kammerman, S. (1973) Characteristics of gonadotropin receptors of porcine granulosa cells during follicle maturation. Endocrinology 92, 531-540.

Cierciorowska, A. \& Russfield, A.B. (1968) Determination of estrogenic activity of the immature rat ovary. Archs Path. 85, 658-664.

Dawson, A.B. \& MCCABE, M. (1951) The interstitial tissue of the ovary in infantile and juvenile rats. J. Morph. 88, 543-571.
GoldenberG, R.L., Vaitukaitis, J.L. \& Ross, G.T. (1972) Estrogen and follicle stimulating hormone interactions and follicle growth in rats. Endocrinology 90, 1492-1498.

Greenwood, F.C., Hunter, W.M. \& Glover, J.S. (1963) The preparation of ${ }^{131}$ I-labelled human growth hormone of high specific radioactivity. Biochem. J. 89, 114-120.

Hertz, R. (1963) Pituitary independence of the prepubertal development of the ovary of the rat and 
rabbit and its pertinence to hypo-ovarism in women. In The Ovary, pp. 120-127. Eds H. G. Grady \& D. E. Smith. Williams \& Wilkins, Baltimore.

Hillensjo, T., Barnea, A., Nilsson, L., Herlitz, H. \& AHRÉn, K. (1974) Temporal relationships between serum LH levels and oocyte maturation in prepubertal rats injected with pregnant mare's serum gonadotropin. Endocrinology 95, 1762-1766.

LOWRY, O.H., ROSEBroUgh, N.J., FARR, A. \& RANDALl, R. (1951) Protein measurement with the Folin phenol reagent. J. biol. Chem. 193, 265-275.

Meiss-Roelofs, H.M.A., UilenBroek, J.TH.J., OSMAN, P. \& Welschen, R. (1974) Serum levels of gonadotropins and follicular growth in prepubertal rats. In The Development and Maturation of the Ovary and its Functions, pp. 3-11. Ed. H. Peters. Excerpta Medica, Amsterdam.

Midgley, A.R. (1972) Autoradiographic analysis of gonadotropin binding to rat ovarian tissue sections. In Receptors for Reproductive Hormones, pp. 365-378. Eds B. W. O'Malley \& A. R. Means. Plenum Press, New York.

Presl, J., Pospísil, J., Figarová, V. \& Wagner, V. (1972) Developmental changes in uptake of radio- activity by the ovaries, pituitary and uterus after ${ }^{125}$ I-labelled human chorionic gonadotrophin administration in rats. J. Endocr. 52, 585-586.

RENNELS, E.S. (1951) Influence of hormones on the histochemistry of ovarian interstitial tissue in the immature rat. Am. J. Anat. 88, 63-107.

Reiter, E.O., Goldenberg, R.L., Vaitukairis, J.L. \& Ross, G.T. (1972) A role for endogenous estrogen in normal ovarian development in the neonatal rat. Endocrinology 91, 1537-1539.

RichaRdS, J.S. (1975) Estradiol receptors content in rat granulosa cells during follicular development: modification by estradiol and gonadotropins. Endocrinology 97, 1174-1184.

Schwartz, N.B., Anderson, C.H., Nequin, L.G. \& ELY, C.A. (1974) Follicular maturation. In Control of the Onset of Puberty, pp. 367-385. Eds M. Grumback, D. Grave \& E. Mayor. Wiley, New York.

Zeleznik, A.J., Midgley, A.R. \& Reichert, L.E. (1974) Granulosa cell maturation in the rat: increased binding of human chorionic gonadotropin following treatment with follicle-stimulating hormone in vivo. Endocrinology 95, 818-825. 